\title{
Bezpieczeństwo jazdy dwuosiowego wagonu towarowego po zwichrowanym torze zakrzywionym
}

\begin{abstract}
$W$ artykule przedstawiono wplyw wybranych parametrów wagonu dwuosiowego takich, jak baza pojazdu, stopień jego obciażenia ładunkiem oraz pionowa sztywność zawieszenia na zagrożenie wykolejeniem na krzywej przejściowej $i$ petnym tuku w przypadku zwichrowania szyny zewnętrznej.

Wykorzystano możliwości obliczeniowe specjalistycznego programu Adams Rail, przeznaczonego do badania dynamiki pojazdów szynowych. Analizowano proces wykolejenia będacy wynikiem wspinania się obrzeża koła na główke szyny. We wszystkich podjętych działaniach ocene poziomu zagrożenia bezpieczeństwa ruchu sprowadzono do analizy wskaźników wykolejenia i pionowego przemieszczenia rejestrowanego na kołach zestawu prowadzacego, $z$ uwzględnieniem kata nabiegania oraz pionowych nacisków kót na szyny wynikajacych z położenia zestawu kót w torze zakrzywionym.
\end{abstract}

\section{WPROWADZENIE}

Znaczna liczba wykolejeń ma miejsce podczas przejazdu pojazdów szynowych przez tor zakrzywiony którego głównymi parametrami geometrycznymi są przechyłka oraz wichrowatość toru. $\mathrm{W}$ prezentowanym artykule jako punkt odniesienia przyjęto normę PN-EN 14363 („Badania właściwości dynamicznych pojazdów szynowych przed dopuszczeniem do ruchu") - [3]. Obszar badań symulacyjnych dotyczył bezpieczeństwa ruchu modelu dwuosiowego wagonu towarowego poruszającego się $\mathrm{z}$ małą prędkością (równą $3 \mathrm{~m} / \mathrm{s}$ ) po torze zakrzywionym o małym promieniu łuku (w rozumieniu normy [3] jest łuk o promieniu $150 \mathrm{~m})$. Bezpieczeństwo analizowano $\mathrm{W}$ aspekcie wykolejenia na krzywej przejściowej oraz na pełnym łuku, na którym zwichrowano szynę zewnętrzną zgodnie z zaleceniami normy PN-EN 14363. Do badań symulacyjnych wykorzystano specjalistyczny program AdamsRail, należący do grupy programów MBS, przeznaczonych do badania dynamiki pojazdów szynowych.

\section{OBIEKT BADAŃ}

\subsection{Pojazd}

W badaniach symulacyjnych wykorzystano model dwuosiowego wagonu towarowego, znajdujący się $\mathrm{w}$ zasobach bibliotecznych programu AdamsRail. Rzeczywistym reprezentantem tego typu konstrukcji jest wagon $\mathrm{z}$ zawieszeniem wieszakowym UICrys.2.1.1. Elementy zawieszenia wagonu (wieszaki 3 oraz resory piórowe 2) przenoszą pionowe obciążenie z nadwozia 1 na obudowy łożysk zestawów kół 4 . Zawieszenie umożliwia zestawom kół wzdłużne i poprzeczne przemieszczenia względem nadwozia.

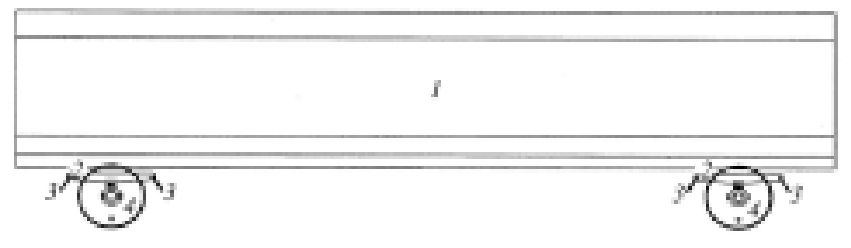

Rys.2.1.1. Strukturalne elementy modelu wagonu towarowego z zawieszeniem wieszakowym UIC - [5]

W zależności od obciążenia wagonu (wagon pusty masa nadwozia równa $20000 \mathrm{~kg}$, wagon pełny - masa nadwozia równa $40000 \mathrm{~kg}$ ) pionowa sztywność zawieszenia przyjęta została zgodnie z progresywną, biliniową charakterystyką zawieszenia pojedynczego koła w kierunku pionowym, przedstawiona na rys.2.1.2. Oznaczało to uwzględnienie sztywności zawieszenia $\mathrm{k}_{\mathrm{z}}=5^{*} 10^{\wedge} 5 \mathrm{~N} / \mathrm{m}$ dla pustego wagonu oraz $\mathrm{k}_{\mathrm{z}}=5^{*} 10^{\wedge} 6 \mathrm{~N} / \mathrm{m}-$ dla całkowicie załadowanego wago$\mathrm{nu}-$ [4]. Sztywność poprzeczną i wzdłużną zawieszenia (w odniesieniu do pojedynczego koła) przyjęto odpowiednio na poziomie $5^{*} 10^{\wedge} 5 \mathrm{~N} / \mathrm{m}$ oraz $1 * 10^{\wedge} 7$ $\mathrm{N} / \mathrm{r}$

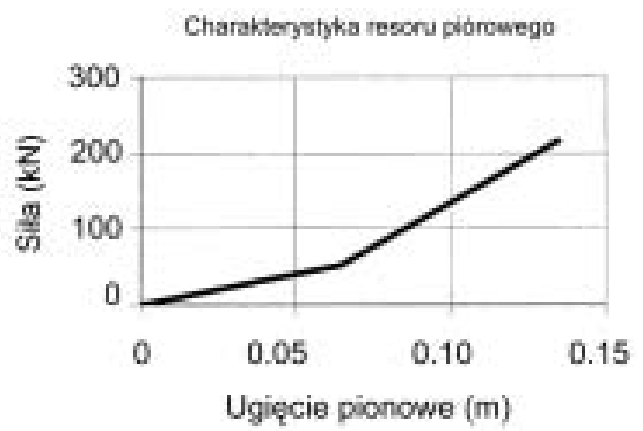

Rys.2.1.2. Charakterystyka zawieszenia pojedynczego koła w kierunku pionowym - [4] 


\subsection{Tor kolejowy}

Geometria toru opisana została przez linię środkową toru, lokalny promień łuku $\mathrm{R}$ oraz lokalną przechyłkę $\mathrm{h}$ - rys.2.2.1. W przypadku odcinka toru prostego promień łuku $\mathrm{R} \rightarrow \infty$ oraz $\mathrm{h}=0$.

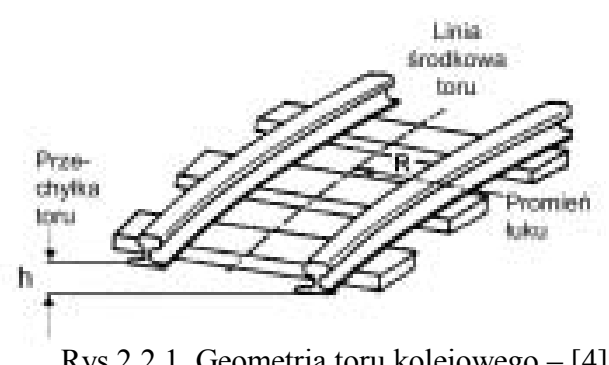

Rys.2.2.1. Geometria toru kolejowego - [4]

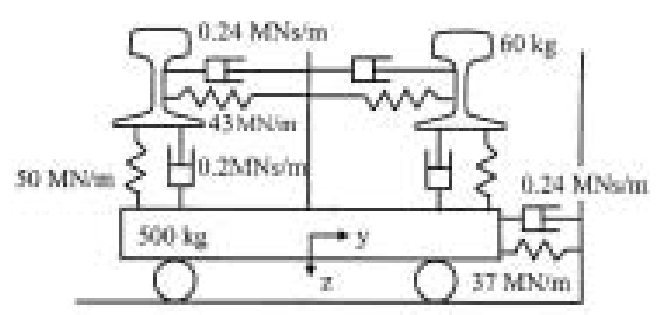

Rys.2.2.2. Reologiczny model toru - [4]

Na krzywej przejściowej wielkości $\mathrm{R}$, h są ciągłymi funkcjami bieżącej długości toru, natomiast na pełnym łuku pozostają stałe. Strukturę toru kolejowego tworzą: stalowe szyny, podkłady, elementy mocujące, podsypka oraz podłoże. Przyjęto reologiczny model toru opisany przez sprężynę o znanej sztywności, połączoną równolegle $\mathrm{z}$ liniowym elementem tłumiącym o znanym thumieniu - rys.2.2.2. Uwzględniona $\mathrm{w}$ obliczeniach zastępcza masa szyny wynosiła $60 \mathrm{~kg}$, natomiast zastępczą masę podkładu, obciążonego zestawem kół, przyjęto równą $500 \mathrm{~kg}$. Do obliczeń sił stycznych pomiędzy kołami i szynami wykorzystano nieliniowy model jednopunktowego styku kół z szynami oraz tablicę kontaktową Kalkera, utworzoną w programie AdamsRail dla kół i szyn o profilach S1002 oraz UIC60. Obliczenia wykonano przy założeniu, że koła wagonu mają nominalną średnicę $0,920 \mathrm{~m}$, zaś współczynnik tarcia między kołem i szyną równy jest 0,4 . Zdefiniowano następujące terminy dotyczące zakrzywionego odcinka toru kolejowego.

\section{1) Przechyłka toru kolejowego}

Przechyłka toru oznacza różnicę wysokości toków szynowych w łuku, w przekroju toru dokonanym w płaszczyźnie pionowej, prostopadłej do linii środkowej toru.

2) Wichrowatość toru kolejowego

Wichrowatość toru kolejowego jest to różnica przechyłek toków szynowych w łuku na długości przyjętej bazy pomiarowej.

Badania przeprowadzone przez zarządy kolei DB, NS, OBB, PKP i SNCF pozwalają ustalić graniczną wartość wichrowatości toru $\mathrm{w}$ powiązaniu $\mathrm{z}$ bazą wzdłużną pojazdu. Wg [3] graniczna wartość $\mathrm{g}_{\text {lim }}$ wichrowatości toru stosowana na europejskich kolejach wynosi:

$$
\mathrm{g}_{\lim }=\min \left(7,0 ; \frac{20}{2 \mathrm{a}}+3\right)[\%] \text {. }
$$

W przypadku badania wichrowatości pojazdu dwuosiowego spełniony powinien być warunek:

$$
\mathrm{g}_{\text {lim }}^{*}=\frac{20}{2 \mathrm{a}}+2[\% \mathrm{o}], \text { jeśli } 4 \mathrm{~m}<2 \mathrm{a} \leq 20 \mathrm{~m} \text {. }
$$

W powyższych wzorach 2a oznacza bazę wzdłużną pojazdu wyrażoną w metrach, przy czym 2a ? $20 \mathrm{~m}$.

$\mathrm{W}$ wykonanych obliczeniach symulacyjnych zmieniano bazę pojazdu w zakresie od 5 do 10 metrów. Wartości wichrowatości toru na odcinku równym długości bazy pojazdu dwuosiowego (obliczone wg wzoru (2)) zebrano w Tabeli 1.

Graniczne wartości wichrowatości toru na odcinku równym bazie pojazdu

Tabela 1.

\begin{tabular}{|c|c|}
\hline $\begin{array}{c}\text { Baza } \\
2 \mathrm{a}(\mathrm{m})\end{array}$ & $\begin{array}{c}\text { Wichrowatość toru na } \\
\text { bazie rozstawu osi } \\
\text { pojazdu ([\%o]) }\end{array}$ \\
\hline 5 & 6 \\
\hline 6 & 5,33 \\
\hline 7 & 4,86 \\
\hline 8 & 4,5 \\
\hline 9 & 4,22 \\
\hline 10 & 4 \\
\hline
\end{tabular}

\section{BEZPIECZEŃSTWO RUCHU POJAZDU SZYNOWEGO NA TORZE ZAKRZY- WIONYM}

Pod uwagę wzięto dwa (najważniejsze zdaniem autorów) wskaźniki pozwalające ocenić poziom bezpieczeństwa modelu pojazdu na torze zakrzywionym. Sa to wskaźnik zagrożenia wykolejeniem Y/Q oraz pionowe przemieszczenie koła $\Delta z$.

1) Wskaźnik zagrożenia wykolejeniem $Y / Q$

Niebezpieczeństwo wspinania się obrzeża koła na główkę szyny oceniane było na podstawie analizy stosunku poprzecznej siły prowadzacej $\mathbf{Y}$ do siły pionowego nacisku $\mathbf{Q}$ koła na szynę. Siła prowadząca $\mathbf{Y}$ jest poprzeczną składową, zaś $\mathbf{Q}$ - pionową składową siły wypadkowej $\mathbf{R}$ w punkcie styku koła z szyna, będącej geometryczną sumą siły $\mathbf{N}$ (normalnej do płaszczyzny styku) oraz siły $\mathbf{T}$ leżącej w płaszczyźnie styku i mającej dwie składowe $T_{x}, T_{y}$ na kierunkach definiujących płaszczyznę styku - rys.3.1.

Wskaźnik zagrożenia wykolejeniem definiowany jest jako stosunek wartości sił Y/Q działających w obszarze styku, w odniesieniu do pojedynczego koła (lewego lub prawego) - rys.3.1. Dla pojedynczego koła wskaźnik ten można opisać analitycznie w następujący sposób (w położeniu równowagi quasi-statycznej zestawu kół wspinającego się na główkę szyny) - [4]: 


$$
\mathrm{Y} / \mathrm{Q}=\frac{-\mathrm{T}_{\mathrm{x}} \mu \sin \psi \cos \alpha / \cos \gamma-\mathrm{T}_{\mathrm{y}} \mu(\cos \psi-\sin \psi \sin \alpha \operatorname{tg} \gamma g+\cos \psi \operatorname{tg} \gamma+\sin \psi \sin \alpha}{\mathrm{T}_{\mathrm{x}} \mu \sin \alpha / \cos \gamma+\mathrm{T}_{\mathrm{y}} \mu \cos \alpha \operatorname{tg} \gamma+\cos \alpha}
$$
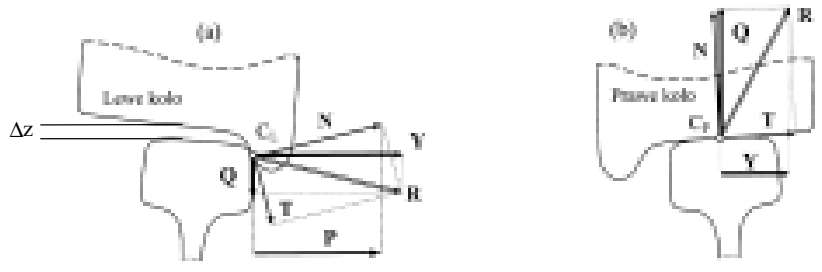

We wzorze (3) kąt $\gamma$ jest kątem styku koła z szyną, $\psi$ jest kątem nabiegania koła na szynę (rys.5.1.6), $\alpha$ oznacza kąt wyprzedzenia nabiegania, natomiast $\mu$ jest ustaloną wartością współczynnika tarcia pomiędzy kołem i szyną.

Pojazd uważany jest za bezpieczny, jeśli w każdym punkcie pomiarowym (punkcie styku koła z szyną na badanym odcinku toru) spełniony jest warunek dotyczący wskaźnika wykolejenia:

w którym $(\mathrm{Y} / \mathrm{Q})_{\max }$ oznacza maksymalną wartość występująca $\mathrm{W}$ punkcie styku koła $\mathrm{z}$ szyną na badanym odcinku toru, uzyskaną $\mathrm{w}$ trakcie obliczeń symulacyjnych, natomiast wartość graniczna $(\mathrm{Y} / \mathrm{Q})_{\lim }$ definiowana jest zgodnie z [3], w następujący sposób:

We wzorze (5) kąt $\delta$ jest kątem zarysu zewnętrznego obrzeża, natomiast $\mu$ oznacza współczynnik tarcia. Dla $\delta=60^{\circ}$ oraz $\mu=0,4$ otrzymujemy $\left|(\mathrm{Y} / \mathrm{Q})_{\lim }\right|=0,78$. Jeżeli na danym kole wartość graniczna $\left|(\mathrm{Y} / \mathrm{Q})_{\lim }\right|$ zostanie przekroczona, sprawdzane jest pionowe przemieszczenie powierzchni tocznej tego koła względem poziomej części główki szyny.

1) Pionowe przemieszczenie koła $\Delta z$

Pionowe przemieszczenie $\Delta z$ powierzchni tocznej względem poziomej części główki szyny pokazane zostało na rys.3.1. Pojazd uważany jest za bezpieczny, jeśli w każdym punkcie pomiarowym spełniony jest następujący warunek - [3]:

gdzie $\Delta \mathrm{z}_{\max }$ oznacza maksymalna wartość pionowego przemieszczenia na odcinku pomiarowym, zaś $\Delta z_{\text {lim }}$ jest wartością graniczną.

\section{ETAPY BADAŃ SYMULACYJNYCH}

Zaplanowano dwa etapy badań modelu dwuosiowego wagonu towarowego na zwichrowanym torze badawczym. W każdym przypadku tor był idealnie gładki, natomiast wichrowatość realizowano po- przez zmianę wysokości położenia szyny zewnętrznej. Ustalona prędkość pojazdu wynosiła za każdym razem $\mathrm{v}=3 \mathrm{~m} / \mathrm{s}$.

\section{Etap pierwszy}

Zwichrowana została zewnętrzna szyna na krzywej przejściowej o promieniu $\mathrm{R}=150 \mathrm{~m}$, na długości toru równej bazie pojazdu. Tor pozostawał idealnie gładki na całej długości - rys.4.1.

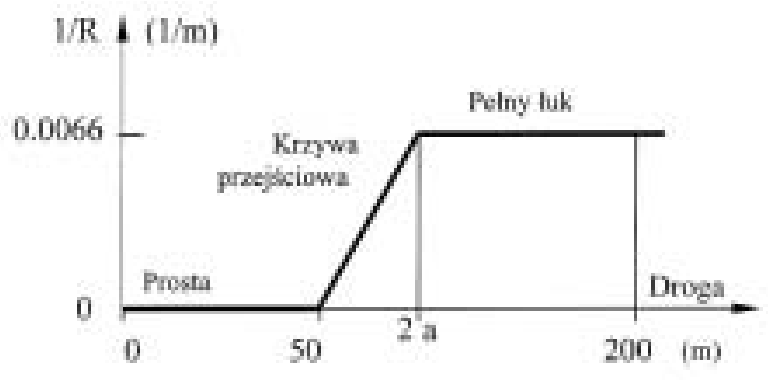

Rys.4.1. Sekcje toru kolejowego ze zwichrowaną zewnętrzna szyną na krzywej przejściowej o promieniu $\mathrm{R}=150 \mathrm{~m}$

\section{Drugi etap}

Zwichrowana została zewnętrzna szyna na pełnym łuku toru o stałym promieniu łuku $\mathrm{R}=150 \mathrm{~m} \mathrm{i}$ przechyłce $0,045 \mathrm{~m}$. Wichrowatość równą 3 [\%o], wprowadzono zgodnie z normą [3], obniżając na długości 30 metrów wysokość szyny zewnętrznej (z $0,045 \mathrm{~m}$ do $-0,045 \mathrm{~m}$ ) względem poziomej płaszczyzny poprzecznej, przechodzącej przez szynę wewnętrzną rys.4.2. Tor pozostawał idealnie gładki na całej długości.

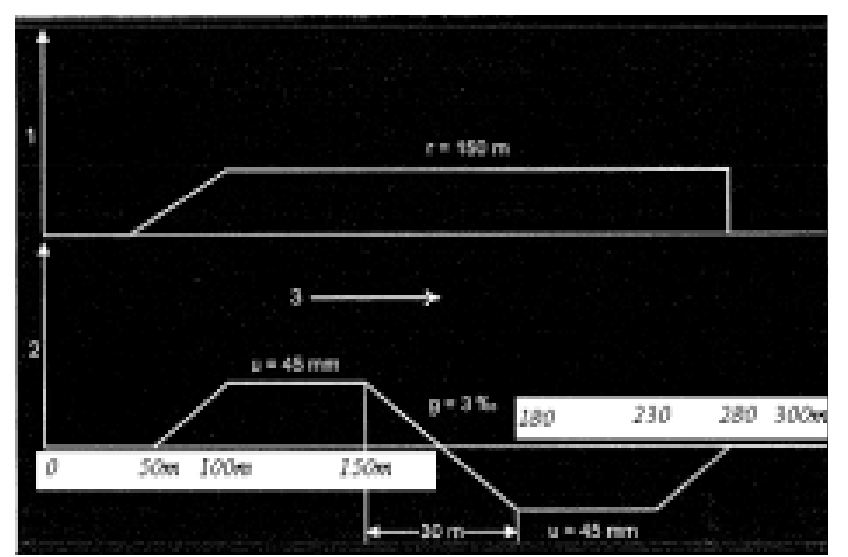

Rys.4.2. Sekcje toru ze zwichrowaną zewnętrzną szyną na pełnym łuku toru o stałym promieniu $\mathrm{R}=150 \mathrm{~m}$ i wichrowatości 3 [\%o] na długości 30 metrów. 1-promień łuku; 2-przechyłka; 3-kierunek jazdy $-[3]$

\section{WYNIKI OBLICZEŃ}

5.1. Zwichrowanie szyny zewnętrznej na krzywej przejściowej

Pierwsza grupa wyników dotyczyła przejazdu pustego i pełnego wagonu z prędkością $3 \mathrm{~m} / \mathrm{s}$ przez idealnie gładki tor zakrzywiony, składający się 
z krzywej przejściowej o długości równej bazie wago$\mathrm{nu}$ i pełnego łuku o promieniu $\mathrm{R}=150 \mathrm{~m}$ ze stałą przechyłką - rys.4.1. Badano zachowanie się pustego oraz całkowicie obciążonego wagonu. Założono, że nadwozie pojazdu jest bryłą idealnie sztywną, posiadającą masę oraz momenty bezwładności. W celu przykładowej wizualizacji wyników przedstawiono (na rysunkach od 5.1.1 do 5.1.4) wartości: pionowych nacisków, wskaźników wykolejenia oraz pionowych przemieszczeń kół zestawu prowadzącego w funkcji drogi (dla pustego wagonu o bazie $5 \mathrm{~m}$ ). Na rys.5.1.5 pokazano również wielkości sił prowadzących na lewym kole zestawu prowadzącego (dla pustego i pełnego wagonu, na krzywej przejściowej i rozwiniętym łuku o promieniu $\mathrm{R}=150 \mathrm{~m}$ ) w funkcji drogi, dla różnych baz wagonu i wartości pionowej sztywności zawieszenia.

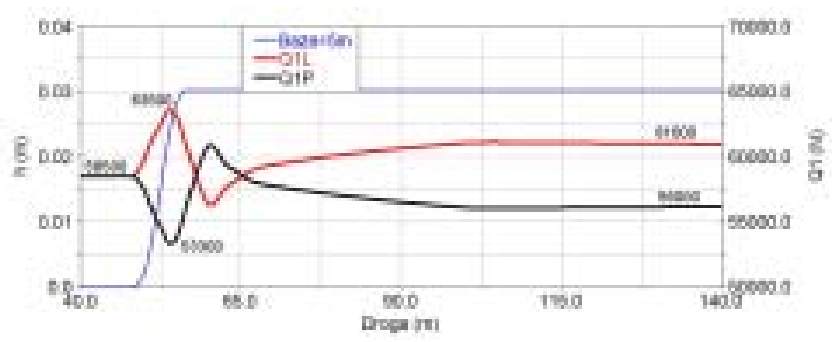

Rys.5.1.1. Pionowe naciski kół na szyny zestawu prowadzącego dla pustego wagonu o bazie równej $5 \mathrm{~m}$, na krzywej przejściowej i rozwiniętym łuku o promieniu $\mathrm{R}=150 \mathrm{~m}$

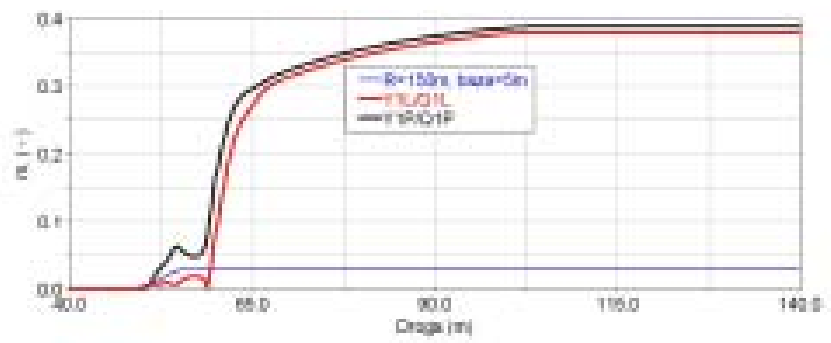

Rys.5.1.2. Wskaźniki wykolejenia $|\mathrm{Y} / \mathrm{Q}|$ na kołach zestawu prowadzącego dla pustego wagonu o bazie równej $5 \mathrm{~m}$, na krzywej przejściowej i rozwiniętym łuku o promieniu $\mathrm{R}=150 \mathrm{~m}$

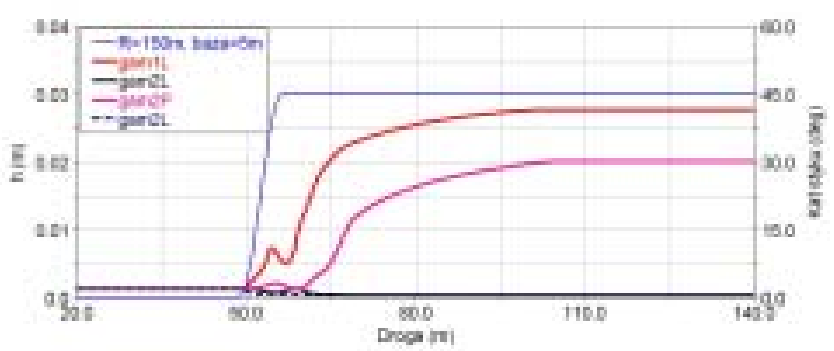

Rys.5.1.3. Kąty styku kół zestawu prowadzącego i zestawu nr 2 dla dla pustego wagonu o bazie równej $5 \mathrm{~m}$, na krzywej przejściowej i rozwiniętym łuku o promieniu $\mathrm{R}=150 \mathrm{~m}$

Wstępne wnioski dotyczące gladkiego toru zakrzywionego z krzywą przejściową i stałą przechyłką na pełnym luku bez wichrowania szyny zewnętrznej

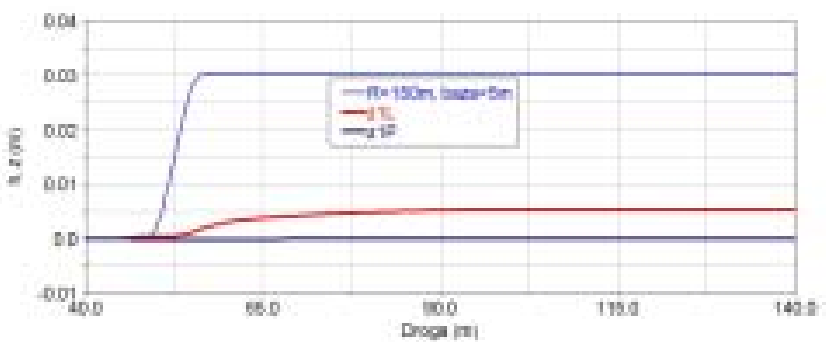

Rys.5.1.4. Pionowe przemieszczenie kół zestawu prowadzącego dla pustego wagonu o bazie równej $5 \mathrm{~m}$, na krzywej przejściowej i rozwiniętym łuku o promieniu $\mathrm{R}=150 \mathrm{~m}$

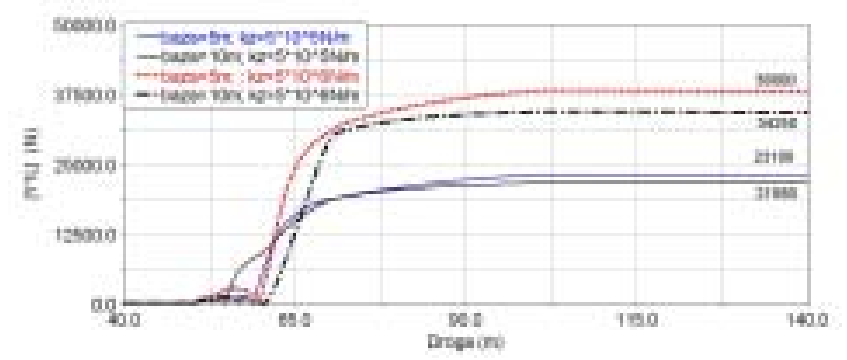

Rys.5.1.5. Siły prowadzące na lewym kole zestawu prowadzącego, dla pustego i pełnego wagonu, na krzywej przejściowej i rozwiniętym łuku o promieniu $\mathrm{R}=150 \mathrm{~m}$

1) $\mathrm{Na}$ torze zakrzywionym zestawy kół pojazdu dwuosiowego przyjmuja położenia prowadzące do zmiany pionowych nacisków kół na szyny. Położenia te charakteryzują się tym, że prowadzący zestaw kół przemieszcza się w kierunku szyny zewnętrznej i nabiega na tę szynę pod dodatnim kątem nabiegania. Drugi zestaw kół przemieszcza się natomiast $\mathrm{W}$ kierunku szyny wewnętrznej i nabiega na nią pod ujemnym kątem nabiegania- rys.5.1.6.

2) Na torze zakrzywionym zmiana nacisków kół na szyny określona jest przez skośno-symetryczny układ zrównoważonych sił. W efekcie tego dwa koła pojazdu są odciążone (zmniejszenie nacisków na kole przednim prawym i tylnym lewym) oraz dwa koła pojazdu są dociążone (zwiększenie pionowych nacisków przedniego lewego i tylnego prawego koła na szynę) rys.5.1.7.

3) Na krzywej przejściowej występują duże, skokowe zmiany wartości pionowych nacisków kół na szyny. Gdy pojazd znajdzie się na pełnym łuku, wartości pionowego dociążenia/odciążenia kół ulegają zmniejszeniu i stabilizują się rys5.1.1.

4) W obrębie krzywej przejściowej bezwzględne wartości wskaźników wykolejenia $|\mathrm{Y} / \mathrm{Q}|$ oraz pionowych przemieszczeń kół są co najmniej o 1 rząd wielkości mniejsze od granicznych wartości, podawanych przez normę - [3]. Zwiększają się one i stabilizują dopiero na pełnym łuku toru kolejowego - rys. $5_{\mathbf{v}}$ ? , rys.5.1.4. 


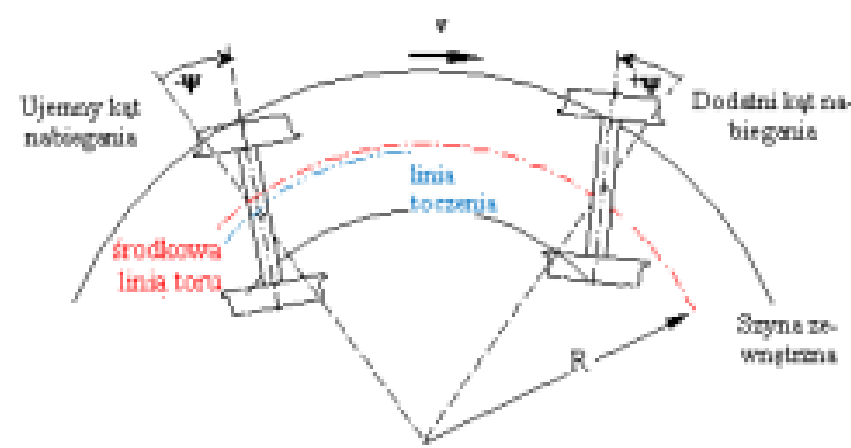

Rys.5.1.6. położenie zestawów kół pojazdu dwuosiowego na zwichrowanym torze zakrzywionym - [4]

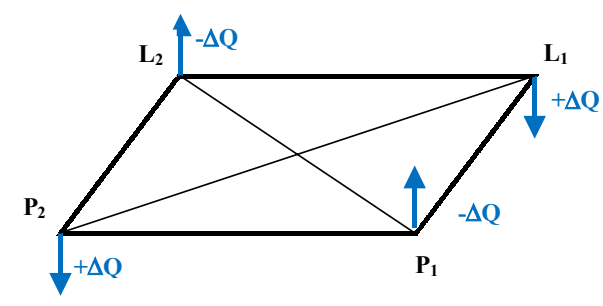

Rys.5.1.7. Odciążenie/dociążenie kół pojazdu dwuosiowego na gładkim torze zakrzywionym (z krzywą przejściową i stałą przechyłką na pełnym łuku)

\subsection{Wpływ pionowej sztywności zawieszenia i bazy pojazdu na bezpieczeństwo ruchu po- jazdu dwuosiowego po torze zakrzywionym}

\subsubsection{Krzywa przejściowa}

Wyniki przedstawiono $\mathrm{w}$ formie graficznej (rysunki od 5.2.1.1 do 5.2.1.6), w funkcji bazy pojazdu oraz pionowej sztywności zawieszenia. Wnioski dotyczące krzywej przejściowej są następujące:

1) Procentowe zmiany pionowych nacisków kół pojazdu na szyny na krzywej przejściowej (w odniesieniu do nacisków statycznych na torze prostym) zależą od pionowej sztywności zawieszenia. Zwiększenie pionowej sztywności zwieszenia o jeden rząd wielkości (z 10^5 N/m do $10^{\wedge} 6 \mathrm{~N} / \mathrm{m}$ ) powoduje niemal czterokrotne zwiększenie wartości przyrostu/spadku pionowych nacisków kół na szyny na krzywej przejściowej - rys.5.2.1.1, rys.5.2.1.2.

2) Nie stwierdzono wyraźnej zależności pomiędzy pionową sztywnością zawieszenia, a wielkościami wskaźników wykolejenia i pionowych przemieszczeń kół - rys.5.2.1.3, rys.5.2.1.4.

3) Można przyjąć, że zarówno zmiany wartości pionowych nacisków kół na szyny, jak i zmiany wartości wskaźników wykolejenia na kołach oraz zmiany pionowych przemieszczeń kół $\mathrm{w}$ funkcji bazy pojazdu dają się opisać wielomianami drugiego stopnia.

4) Największe wartości wskaźników wykolejenia na krzywej przejściowej skręcającej w prawo obserwowane są na prawym kole zestawu prowadzącego - rys.5.2.1.3.
5) Pionowe przemieszczenia kół na krzywej przejściowej występują na kołach odciążonych, a ich maksymalne wartości na lewym kole zestawu prowadzącego nie stanowią realnego zagrożenia wykolejeniem - rys.5.2.1.5.

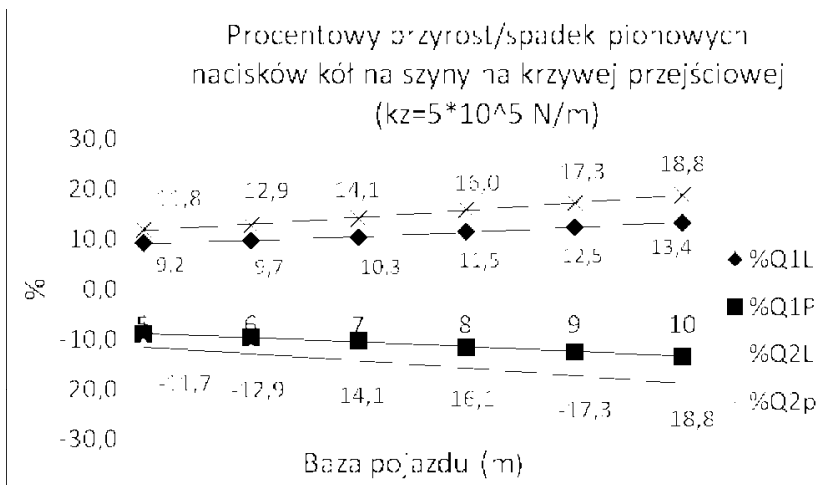

Rys.5. 2.1.1. Procentowy przyrost/spadek wartości pionowych nacisków kół na szyny w funkcji bazy pojazdu, dla pustego wagonu dwuosiowego na krzywej przejściowej

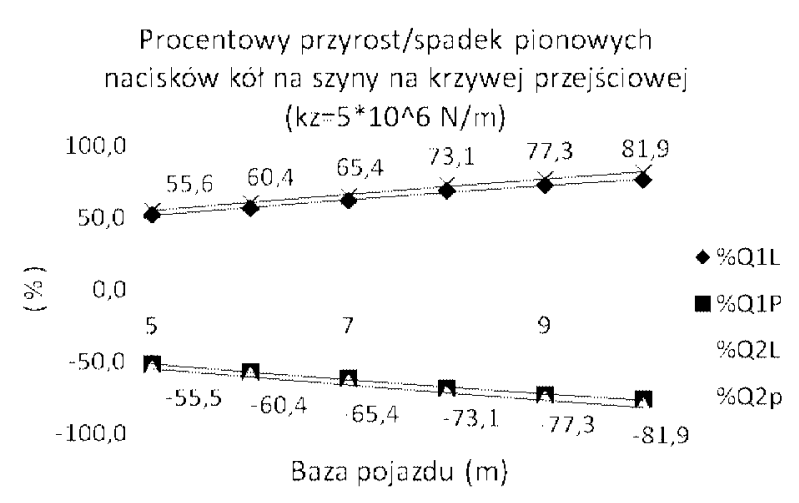

Rys.5.2.1.2. Procentowy przyrost/spadek wartości pionowych nacisków kół na szyny w funkcji bazy pojazdu, dla całkowicie obciążonego wagonu dwuosiowego na krzywej przejściowej

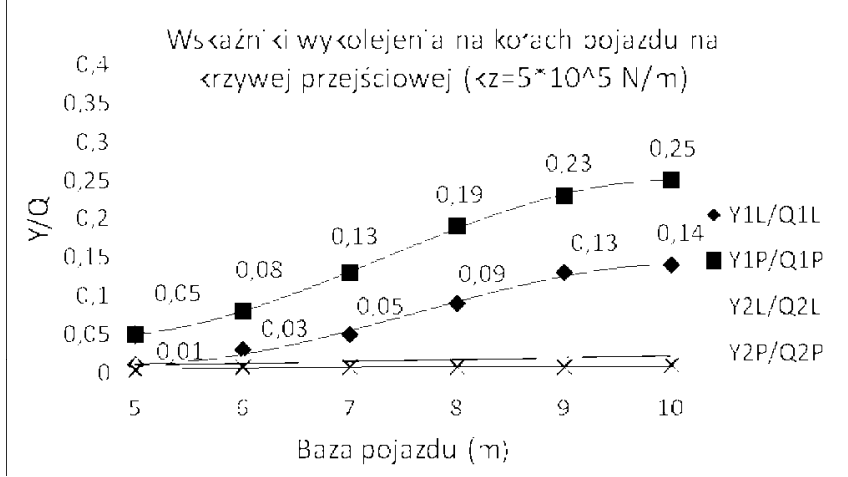

Rys.5.2.1.3. Wskaźniki wykolejenia na kołach w funkcji bazy pojazdu, dla pustego wagonu dwuosiowego na krzywej przejściowej 


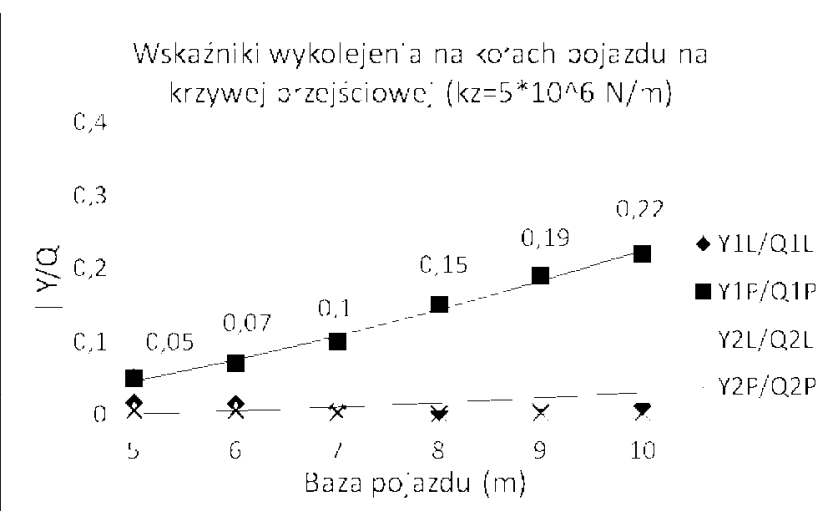

Rys.5.2.1.4. Wskaźniki wykolejenia na kołach w funkcji bazy pojazdu, dla całkowicie obciążonego wagonu dwuosiowego na krzywej przejściowej

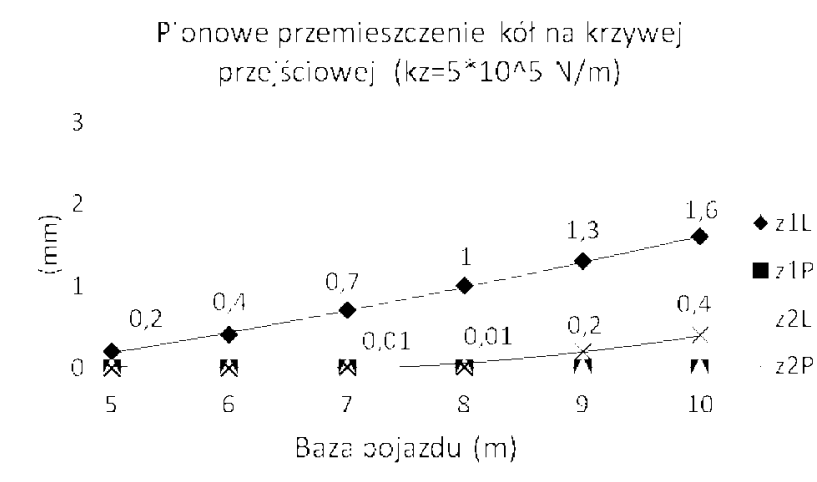

Rys.5.2.1.5. Pionowe przemieszczenie kół w funkcji bazy pojazdu, dla pustego wagonu dwuosiowego na krzywej przejściowej

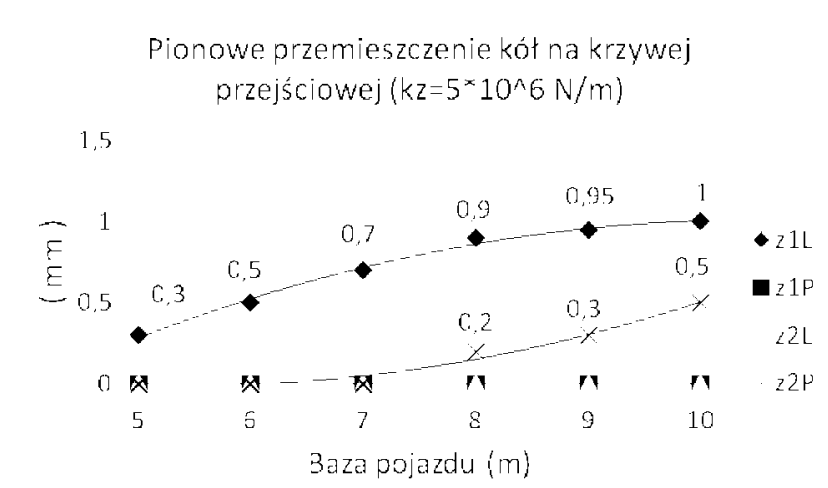

Rys.5.2.1.6. Pionowe przemieszczenie kół w funkcji bazy pojazdu dla całkowicie obciążonego wagonu dwuosiowego na krzywej przejściowej

\subsubsection{Pelny luk toru zakrzywionego ze stałą prze- chyłką bez zwichrowania szyny zewnętrznej}

Wnioski dotyczące pełnego łuku bez jego zwichrowania są zbliżone do tych dla krzywej przejściowej:

1) Procentowe zmiany nacisków (w odniesieniu do nacisków statycznych) na kołach pojazdu zależą od pionowej sztywności zawieszenia.

2) Zwiększenie pionowej sztywności zawieszenia o jeden rząd wielkości (z 10^5 N/m do $10^{\wedge} 6 \mathrm{~N} / \mathrm{m}$ ) powoduje prawie dwukrotne zwiększenie/spadek wartości pionowych nacisków kół na szyny - rys.5.2.2.1, rys.5.2.2.2.

3) Wartości wskaźników wykolejenia na kołach oraz pionowych przemieszczeń kół w funkcji bazy pojazdu daja się opisać wielomianami drugiego stopnia.

4) Największe wartości wskaźników wykolejenia obserwowane są na prawym kole zestawu prowadzącego - rys.5.2.2.4.

5) Maksymalne wartości pionowe przemieszczeń kół obserwowane są w wagonie całkowicie obciążonym na lewym kole zestawu prowadzącego - rys.5.2.2.6.

Przyrost/spadek pionowych nacisków kół na szyny petriym tuku bec cwichrowaria $\left(k<=5 * 10^{\wedge} 5 \mathrm{~N} / \mathrm{m}\right)$

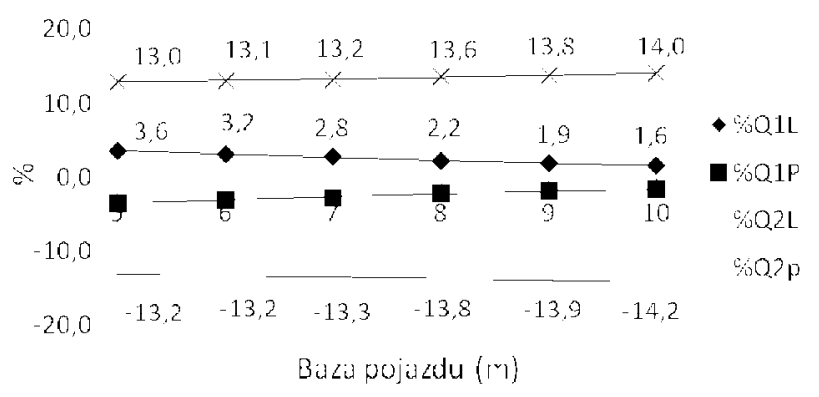

Rys.5. 2.2.1. Procentowy przyrost/spadek wartości pionowych nacisków kół na szyny w funkcji bazy pojazdu, dla pustego wagonu dwuosiowego na pełnym łuku bez zwichrowania

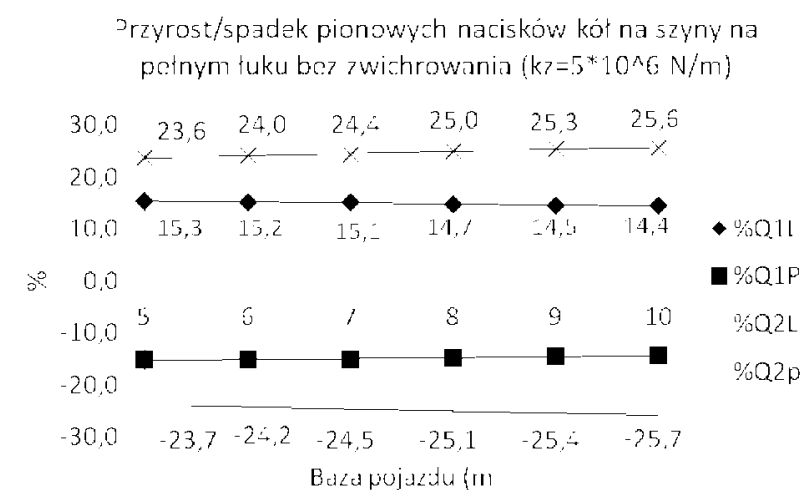

Rys.5.2.2.2. Procentowy przyrost/spadek wartości pionowych nacisków kół na szyny w funkcji bazy pojazdu, dla całkowicie obciążonego wagonu dwuosiowego na pełnym łuku bez zwichrowania

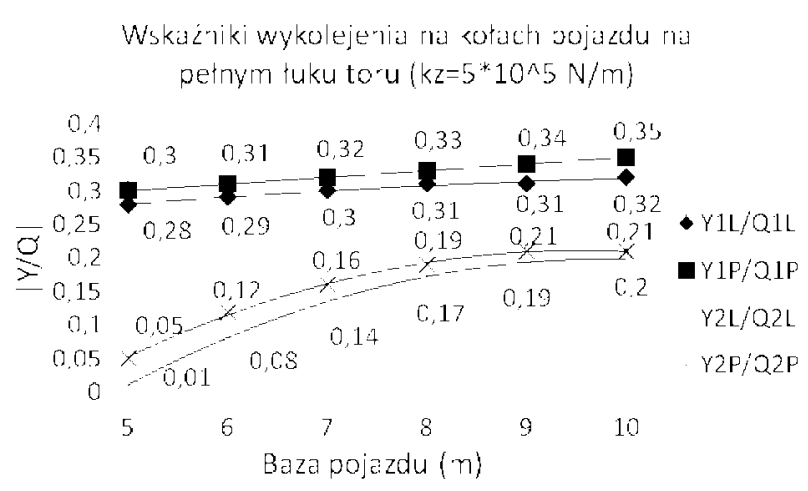

Rys.5.2.2.3 Wskaźniki wykolejenia na kołach w funkcji bazy pojazdu, dla pustego wagonu dwuosiowego na pełnym łuku bez wichrowania 


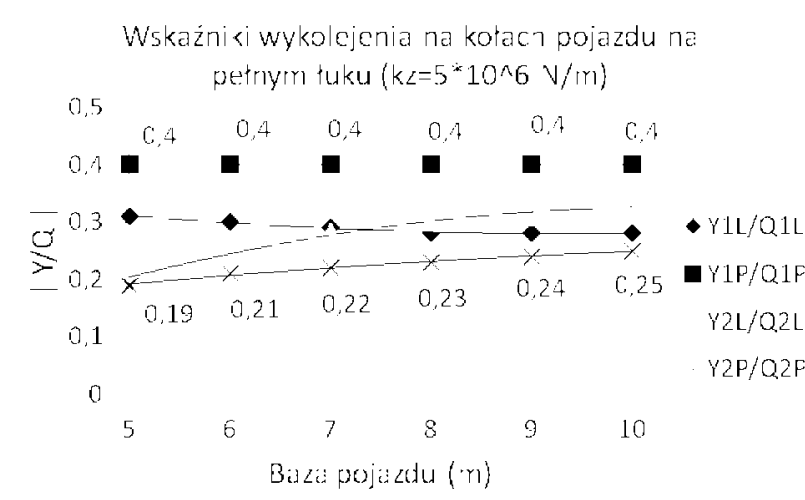

Rys.5.2.2.4. Wskaźniki wykolejenia na kołach w funkcji bazy pojazdu, dla całkowicie obciążonego wagonu dwuosiowego na pełnym łuku bez wichrowania

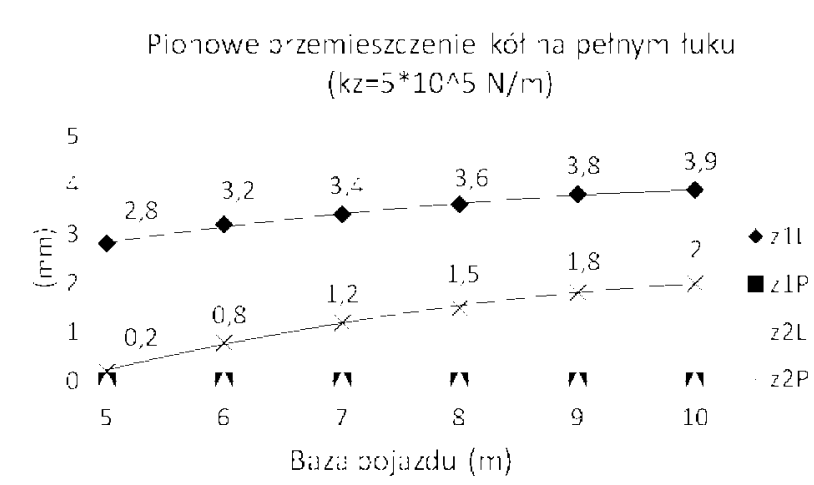

Rys.5.2.2.5. Pionowe przemieszczenie kół w funkcji bazy pojazdu, dla pustego wagonu dwuosiowego na pełnym łuku bez wichrowania

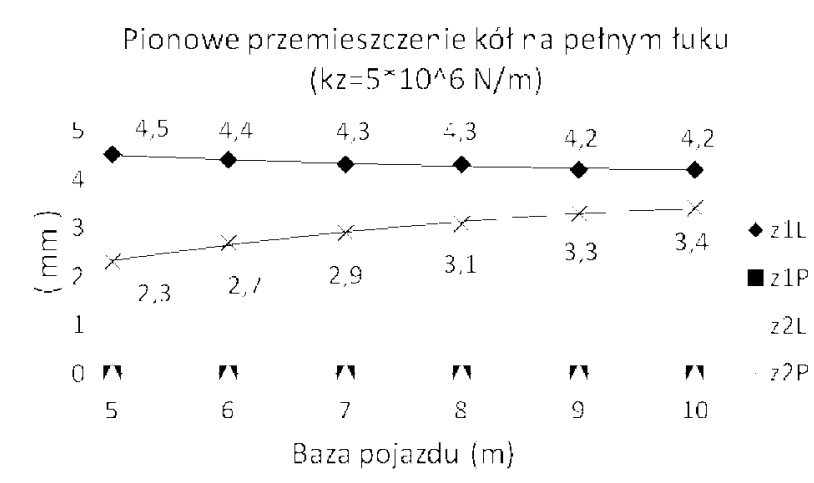

Rys.5.2.2.6. Pionowe przemieszczenie kół w funkcji bazy pojazdu dla całkowicie obciążonego wagonu dwuosiowego na pełnym łuku bez wichrowania

\subsubsection{Pelny luk toru zakrzywionego ze zwichro- waną szyną zewnętrzną}

Zewnętrzną szynę toru gładkiego zwichrowano na pełnym łuku, zgodnie z PN-EN 14363. Wyniki przedstawiono $\mathrm{w}$ funkcji bazy pojazdu oraz pionowej sztywności zawieszenia. Wnioski dotyczące toru zakrzywionego zwichrowanego na pełnym łuku są następujące:

1) Procentowe zmiany nacisków (w odniesieniu do nacisków statycznych) na kołach pojazdu zależą od pionowej sztywności zawieszenia.
2) Zwiększenie pionowej sztywności zawieszenia o jeden rząd wielkości (z 10^5 N/m do $10^{\wedge} 6 \mathrm{~N} / \mathrm{m}$ ) powoduje prawie dwukrotne zwiększenie wartości przyrostu/spadku pionowych nacisków kół na szyny - rys.5.2.3.1, rys.5.2.3.2.

3) Wartości wskaźników wykolejenia na kołach oraz pionowych przemieszczeń kół w funkcji bazy pojazdu dają się opisać wielomianami drugiego stopnia.

4) Największe wartości wskaźników wykolejenia obserwowane są na lewym kole zestawu prowadzącego. Liczbowe wartości tych wskaźników osiagaja poziom $|\mathrm{Y} / \mathrm{Q}|=0,71$ dla wagonu całkowicie załadowanego (o bazie $10 \mathrm{~m}$ ) i zbliżają się do wartości granicznych - rys.5.2.3.4.

5) Pionowe przemieszczenia kół występują na kołach odciążonych, a ich maksymalne wartości dla każdej rozpatrywanej bazy pojazdu przekraczają dopuszczalne wartości graniczne podawane $\mathrm{w}$ nor$\operatorname{mie}\left(\Delta z_{\max }>5 \mathrm{~mm}\right)-$ rys.5.2.3.5, rys.5.2.3.6.

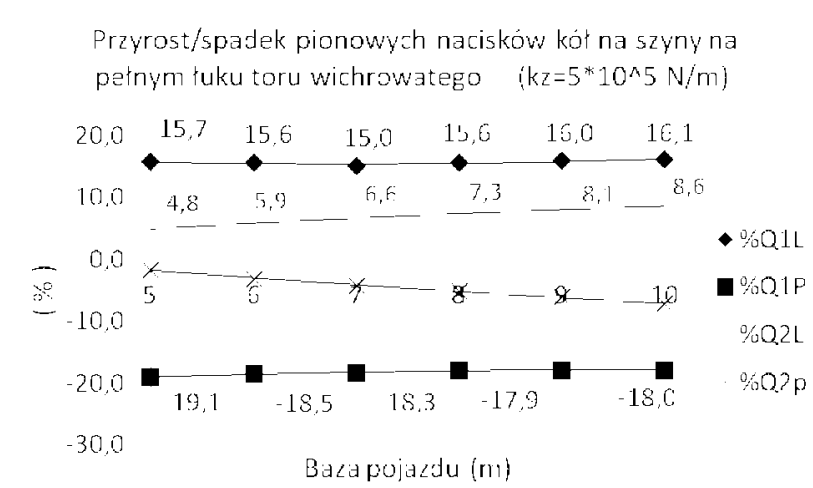

Rys.5. 2.3.1. Procentowy przyrost/spadek wartości pionowych nacisków kół na szyny w funkcji bazy pojazdu, dla pustego wagonu dwuosiowego na pełnym łuku zwichrowanym

\section{Trzyrost/spadek pionowych naciskow kół na szyny na petnym uku toru wichrowatego $\left(k z=5 * 1 C^{\wedge} G \mathrm{~V} / \mathrm{m}\right)$}

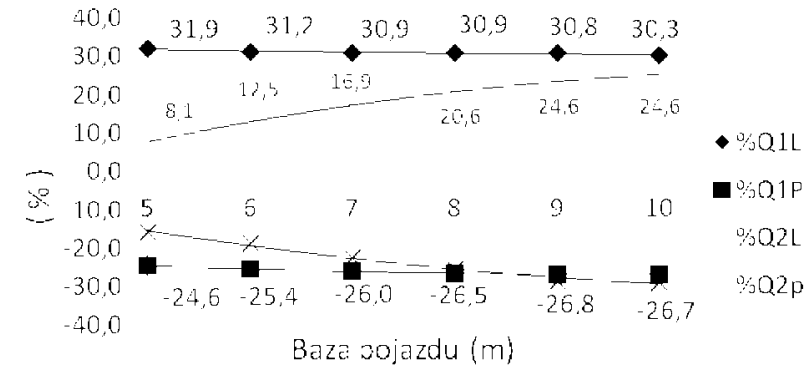

Rys.5.2.3.2. Procentowy przyrost/spadek wartości pionowych nacisków kół na szyny w funkcji bazy pojazdu, dla całkowicie obciążonego wagonu dwuosiowego na pełnym łuku zwichrowanym 


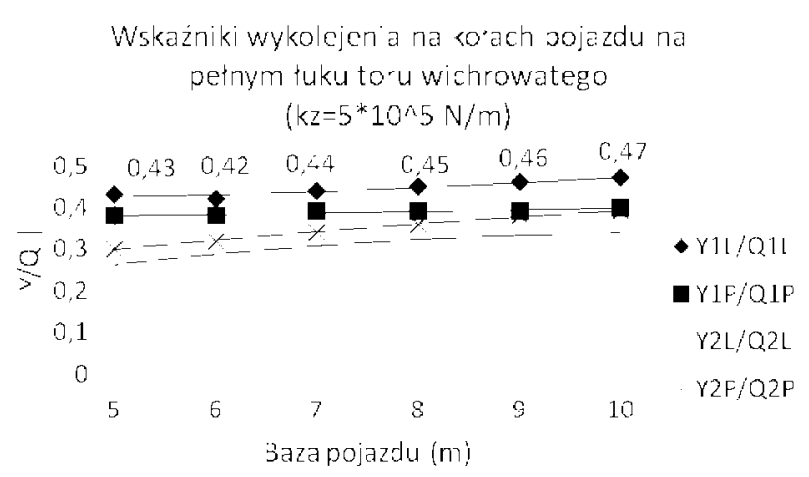

Rys.5.2.3.3. Wskaźniki wykolejenia na kołach w funkcji bazy pojazdu, dla pustego wagonu dwuosiowego na pełnym łuku zwichrowanym zgodnie z PN-EN 14363

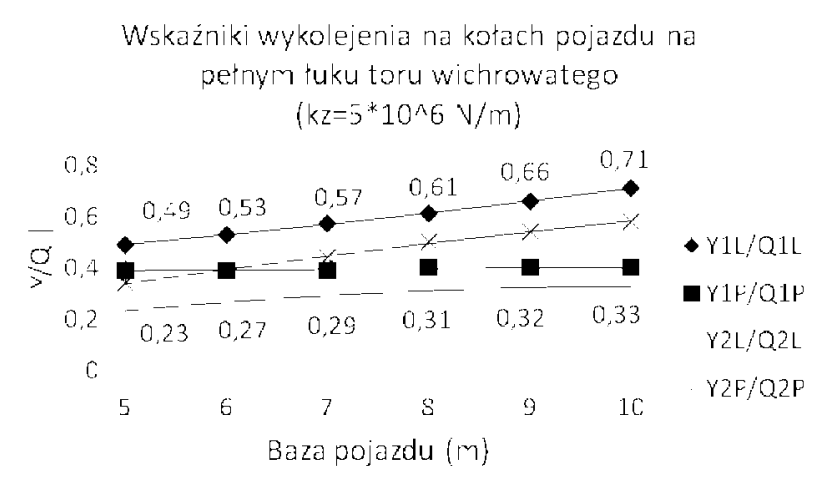

Rys.5.2.3.4. Wskaźniki wykolejenia na kołach w funkcji bazy pojazdu, dla pełnego wagonu dwuosiowego na pełnym łuku zwichrowanym zgodnie z PN-EN 14363

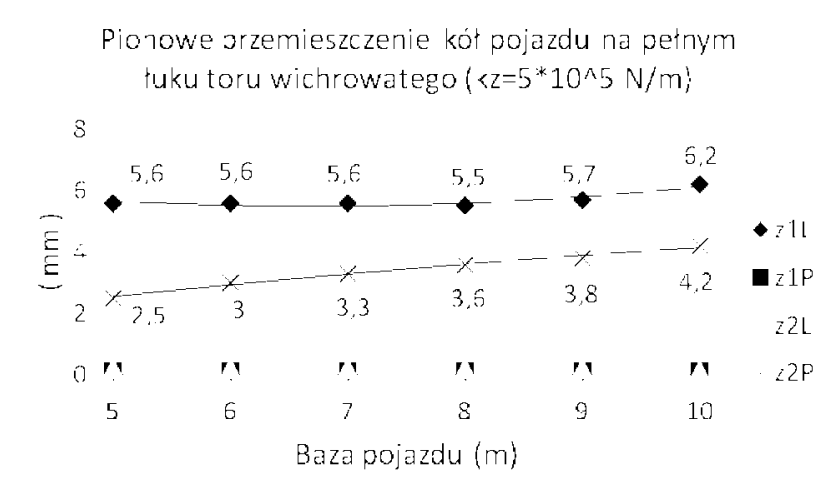

Rys.5.2.3.5. Pionowe przemieszczenie kół w funkcji bazy pojazdu, dla pustego wagonu dwuosiowego na pełnym łuku zwichrowanym zgodnie z PN-EN 14363

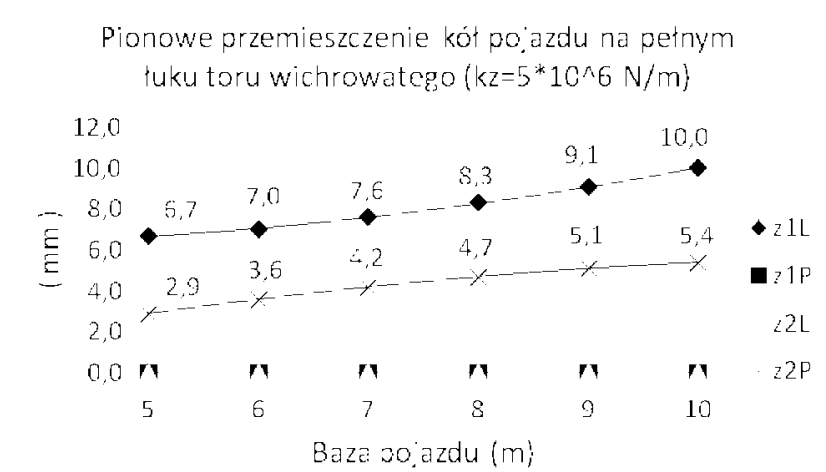

Rys.5.2.3.6. Pionowe przemieszczenie kół w funkcji bazy pojazdu, dla pełnego wagonu dwuosiowego na pełnym łuku zwichrowanym zgodnie z PN-EN 14363

\section{WNIOSKI KOŃCOWE}

Po analizie uzyskanych wyników obliczeń, autorzy artykułu doszli do następujących wniosków:

1) Duże, skokowe zmiany wartości pionowych nacisków kół na szyny występują tylko na krzywej przejściowej. Gdy pojazd znajdzie się na pełnym łuku, wartości pionowego dociążenia/odciążenia kół ulegają zmniejszeniu i stabilizują się. Pionowe odciążenie kół dwuosiowego pojazdu szynowego na krzywej przejściowej nie jest jednak główną przyczyną wykolejenia. Zauważono bowiem, że w obrębie krzywej przejściowej bezwzględne wartości wskaźników wykolejenia $|\mathrm{Y} / \mathrm{Q}|$ oraz pionowych przemieszczeń kół (czyli głównych wskaźników, na postawie których wnioskowano o bezpieczeństwie) są co najmniej o 1 rząd wielkości mniejsze od granicznych wartości, podawanych przez normę PN-EN 14363. Bezwzględne wartości tych wskaźników zwiększają się i stabilizują dopiero na pełnym łuku toru kolejowego.

2) Wcześniejszy wniosek wypływa $z$ faktu, że w procesie wykolejenia związanego ze wspinaniem się obrzeża koła na główkę szyny, decydującą rolę odgrywa położenie zestawu kół w torze kolejowym oraz siły prowadzące.

Do kontaktu obrzeża koła z szyną i wspinania się jego na główkę szyny najczęściej dochodzi w wyniku zwiększenia się wartości siły prowadzącej, działającej na to koło.

Taka sytuacja ma zawsze miejsce na pełnym łuku toru zakrzywionego. Dlatego uzasadnione jest badanie pojazdu na pełnym tuku toru zakrzywionego w sytuacji, gdy zwichrowaniu ulega szyna zewnętrzna, co w całości pokrywa się $\mathrm{z}$ wymogami stawianymi przez normę PN-EN 14363.

3) $\mathrm{Na}$ zwichrowanym tuku toru zakrzywionego najbardziej narażonym na wykolejenie jest prowadzący zestaw kół.

4) Stwierdzono istotny wpływ sztywności pionowej zawieszenia, zarówno na graniczne wartości wskaźników wykolejenia, jak i na wartości pionowych przemieszczeń koła ponad główkę szyny.

Zwiększenie sztywności pionowej zawieszenia o 1 rząd wielkości (od $1 * 10^{\wedge} 5 \mathrm{~N} / \mathrm{m}$ do $\left.1 * 10^{\wedge} 6 \mathrm{~N} / \mathrm{m}\right)$ powoduje zwiększenie wartości wskaźników wykolejenia o ok. $50 \%$ oraz wartości pionowych przemieszczeń koła o ok. $70 \%$.

\section{LITERATURA}

[1] Chojnacki, A., Walczak, S.: Badania bezpieczeństwa jazdy po wichrowatym torze. Porównanie wymagań wg ORE, PN-EN i TSI. Pojazdy Szynowe, nr 2/2011, s.3438. 
[2] Gasowski, W., Marciniak, Z.: Konstrukcje oraz modele wózków $i$ układów zawieszeń wagonów $i$ lokomotyw przeznaczonych do jazdy z dużymi prędkościami. Wydawnictwo Politechniki Poznańskiej, Poznań 1993.

[3] Norma PN-EN 14363.: Badania właściwości dynamicznych pojazdów szynowych przed dopuszczeniem do ruchu. PKN, Warszawa 2007.
[4] Matej, J.: Modelowanie oraz symulacyjne badania wagonów bimodalnych $w$ kategoriach zagrożenia wykolejeniem. Prace Naukowe, Mechanika, z. 234. Oficyna Wydawnicza Politechniki Warszawskiej, Warszawa 2010.

[5] Matej, J.: Symulacyjna metoda oceny poziomu zagrożenia wykolejeniem wagonu towarowego na torze prostym. Przeglad Mechaniczny, Nr 1/2011, s. 20-25. 